Digging into the Dark Ages

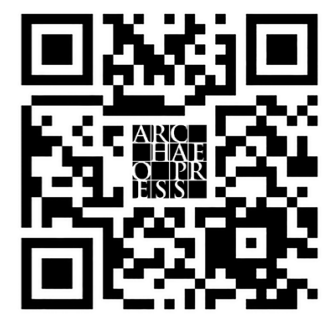




\section{About Access Archaeology}

Access Archaeology offers a different publishing model for specialist academic material that might traditionally prove commercially unviable, perhaps due to its sheer extent or volume of colour content, or simply due to its relatively niche field of interest. This could apply, for example, to a PhD dissertation or a catalogue of archaeological data.

All Access Archaeology publications are available in open-access e-pdf format and in print format. The open-access model supports dissemination in areas of the world where budgets are more severely limited, and also allows individual academics from all over the world the opportunity to access the material privately, rather than relying solely on their university or public library. Print copies, nevertheless, remain available to individuals and institutions who need or prefer them.

The material is refereed and/or peer reviewed. Copy-editing takes place prior to submission of the work for publication and is the responsibility of the author. Academics who are able to supply print-ready material are not charged any fee to publish (including making the material available in open-access). In some instances the material is type-set in-house and in these cases a small charge is passed on for layout work.

Our principal effort goes into promoting the material, both in open-access and print, where Access Archaeology books get the same level of attention as all of our publications which are marketed through e-alerts, print catalogues, displays at academic conferences, and are supported by professional distribution worldwide.

Open-access allows for greater dissemination of academic work than traditional print models could ever hope to support. It is common for an open-access e-pdf to be downloaded hundreds or sometimes thousands of times when it first appears on our website. Print sales of such specialist material would take years to match this figure, if indeed they ever would.

This model may well evolve over time, but its ambition will always remain to publish archaeological material that would prove commercially unviable in traditional publishing models, without passing the expense on to the academic (author or reader).

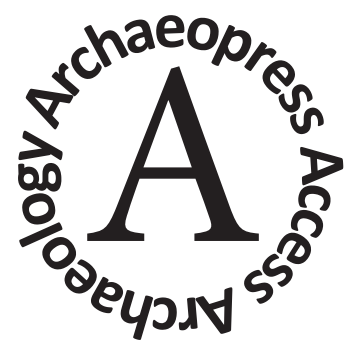




\section{Digging into the Dark Ages}

Early Medieval Public Archaeologies

edited by

Howard Williams and Pauline Clarke
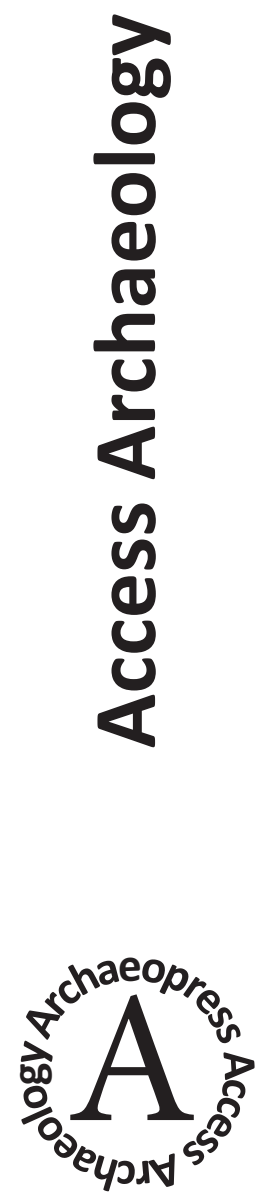


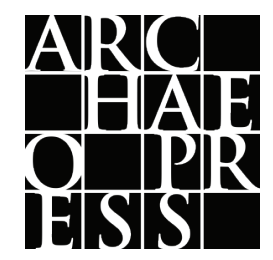

ARCHAEOPRESS PUBLISHING LTD

Summertown Pavilion

18-24 Middle Way

Summertown

Oxford OX2 7LG

www.archaeopress.com

ISBN 978-1-78969-527-4

ISBN 978-1-78969-528-1 (e-Pdf)

(C) The individual authors and Archaeopress 2020

Cover images:

Top-left: Donaeld the Unready's Casket (posted to Twitter on 15 September 2018), based on the Franks Casket (Wulgar the Bard, 2018)

Top-right: 'Gallos' sculpture by Rubin Eynon on the cliffs at Tintagel (Photograph: Susan Greaney)

Bottom-left: View of the 2012 third season of excavations on the western side of the mound beneath the Pillar of Eliseg (Photograph: Howard Williams, 2012)

Bottom-right: Viðarr and Fenrir scanned from the Gosforth Cross, east side (C) (Scan by D. Powlesland with overlay by R.Lang from Parker and Collingwood 1917: 101)

All rights reserved. No part of this book may be reproduced, stored in retrieval system, or transmitted, in any form or by any means, electronic, mechanical, photocopying or otherwise, without the prior written permission of the copyright owners.

This book is available direct from Archaeopress or from our website www.archaeopress.com 


\title{
Archaeology in Alfred the Great (1969) and The Last Kingdom (2015-)
}

\author{
Victoria Nicholls and Howard Williams
}

\begin{abstract}
Alfred the Great (1969) was the first, and remains the only, feature-length film portraying the West Saxon king and his conflicts with the Danes. Forty-seven years later, Bernard Cornwell's novels have been adapted for television as The Last Kingdom (2015-). Despite being fictional adaptions of historical events, and despite the considerable separation in time between their production, both Alfred the Great and The Last Kingdom consciously aspired to portray the Saxons and Vikings with a high degree of historical accuracy. Taking an archaeological perspective - focusing on the material cultures represented and their archaeological inspirations - this chapter asks which is more effective in representing late 9th-century Britain and what are the implications of this comparison?
\end{abstract}

\section{Introduction}

The portrayal of the Viking world in films and television dramas has received modest attention, and with relatively little consideration regarding the character and accuracy of the material cultures deployed (e.g. Hall 2009; Harty 2011; Tveskov and Erlandson 2007). Only recently, and primarily in relation to the History Channel's Vikings, have the artefacts, materials, built environments and landscapes of these modern media of entertainment started to be evaluated, and only in the context of death rituals (see Williams 2019a). This chapter aims to broaden this field of enquiry and adopts a comparative approach. Both the 1969 film Alfred the Great (AtG), and the ongoing BBC television series The Last Kingdom (TLK) (2015-present), represent late ninth-century Wessex, the Danelaw and Northumbria on screen (plus forays elsewhere), depicting both the Anglo-Saxons and Danes (Northmen) in the context of Alfred the Great's reign. Each of these productions claimed at the time of their release to have represented the 9th century as accurately as possible, and for TLK this is taken to extreme lengths of hyperbole by the production team and actors in an online video: The Last Kingdom: Creating the World (SomeHistoryStuff 2016). This chapter will evaluate these claims from an archaeological perspective by comparing and contrasting the representation of three prevalent forms of material culture in each production: brooches, swords and ships.

\section{Brooches}

Both productions deploy brooches replicating and/or inspired by early medieval archaeological finds. Throughout AtG, Alfred and other lead Anglo-Saxon characters wear numerous brooches, but the choices are incongruous in archaeological terms. In one scene, King Alfred wears a pair of square-headed brooches known mainly from early 6th-century furnished inhumation graves as a high-status element of female-gendered dress accessories (Hines 1997). Alfred wears them as a pair on the shoulders fastening his cloak to his tunic rather than singly as found in female-gendered burial assemblages of over three centuries earlier! The disc brooch Alfred wears in another scene also has 6th-century parallels. Finally, a third brooch worn by Alfred matches closely to an 8th-century example of a penannular brooch. Alfred's West Saxon costume is therefore differentiated from the Danes by selecting pre-Viking Insular items, but including items that would challenge early medieval conventions of gendered costume. By way of contrast, the Danish leader Guthrum is depicted wearing a pair of Irish penannular brooches that would not be implausible in the context of the 8th or 9th centuries in the context of elite male costume, but again they would not be worn as a pair (Ó Flionn 1989; e.g. Ashby and Leonard 2018: 132-133). The gender confusion is more striking in another scene where Guthrum wears a pair of tortoise brooches: a contemporaneous and Scandinavian style of dress, and in these regards broadly accurate, but again 
these are items inferred to be exclusively female-gendered in the Viking world (e.g. Hinton 2005: 117-118; Paterson et al. 2014: 53-67)! So both the ruler of the West Saxons and the Danes deploy female brooches, operating centuries out of their archaeological data-range in the case of Alfred but more contemporaneous for Guthrum.

TLK struggles with the same gender and ethnic incongruities. The brooches shown worn by lead characters in TLK Season 1 are centuries out of their proper context. In one striking case the brooch is too young and likely have crossed over gender lines: the Urnes-style brooch worn by Odda the Elder in Season 1 is at least two centuries too early (Graham-Campell 2013: 133-135). Conversely, Odda the Younger wears a small square-headed brooch like those found in female-gendered burial assemblages in the early 6th century AD from east Kent and Merovingian Gaul (e.g. brooch DVB 407 from Buckland, Dover) (Soulat 2016: 21). While Viking-period in date, again on gender and ethnic grounds it is strikingly odd to see the West Saxon King Aethelberht wearing a trefoil brooch of Scandinavian style whilst in his court in Winchester (Pestell 2015: 234-238; Williams 2018a).

At $G$ and TLK therefore have a lot in common despite four-and-a-half decades separating their production. Both deploy early medieval brooches but with stark incongruitites in terms of chronology, gender and ethnicity. A distinction can be made between the two productions, however, when we come to consider the dress accessories deployed in TLK Season 2. Here, the West Saxon ruler wears an exact replica of the 9th-century silver Fuller Brooch (Hinton 2005: 110-112; Williams 2018a; Wilson 1964: 211-214), and thus a distinctive choice of a brooch of the right date, provenance and high-status associations. Likewise, at another point in Season 2, Alfred wields the famous Alfred Jewel, although represented unfortunately in its modern-day broken state (Ashby and Leonard 2018: 40; Hinton 2005: 129-131; Webster 2012: 152, 154; Williams 2019c)! It seems that attempts are being made in Season 2 to escape the anachronisms of Season 1 , even if the artefacts can appear as broken items.

In summary, both productions draw on the archaeological record and seem intent on adorning lead male Anglo-Saxon and Danish characters with female dress accessories from centuries earlier or later. Yet for TLK, there is a concerted effort, specifically in Season 2, to represent actual famous archaeological finds into the storyline as worn and used by key historical personages of the late $9^{\text {th }}$ century. Having said that, the burgeoning evidence for later Anglo-Saxon and Anglo-Scandinavian dress accessories from excavations and metal-detector finds over the last half-century does not seem to have left an impression on the material world of TLK (e.g. Kershaw 2013).

\section{Swords}

While there are many critical comments one could make of both productions regarding weapons and armour, this brief discussion will focus on swords: the highest status and most prized martial implement of 9th-century Britain. Here, the tables are turned. The significant sword used in several scenes throughout the film AtG possesses many similarities to archaeological discoveries of $9^{\text {th }}$-century weapons, notably the hilt which closely parallels the Abingdon Sword which is of a quality to plausibly be a weapon wielded by West Saxon royalty or ealdormen (Hinton 2005: 110-111, 131; Wilson 1964, plate VI; Webster 2012: 156-157) and it bears an inscribed Frankish blade (Davidson 1962: 42-50). Many other swords are generally accurate in general terms, but no detailed evaluation can be made: after all, around 1,600 swords were made for AtG (Galway Advertiser 2018).

In contrast, TLK departs from any archaeological groundings in its most widely represented blade: the sword carried by Uthred throughout bears few similarities to any known Viking-period weapons and is implausibly worn in a back-scabbard. While the blade and guard crudely match with the archaeological examples (Graham-Campbell 2013: 30), the grip and pommel are fanciful. More specifically, there are 
no swords that match the amber fixed to the top of the pommel, which looks plain bizarre in an early medieval context (see Williams 2018a). So if TLK, despite many mistakes, can be shown to have a slight advantage over AtG in regards to brooches, it fails to impress in its representation of swords and AtG wins hands down.

\section{Ships}

A higher degree of equivalent accuracy can be identified for each production when in comes to the replica seagoing vessels deployed. Thanks to the discoveries of the Gokstad and Oseberg ships and their display in Vikingskipshuset, Oslo, filmic and televisual representations of Viking longships have a long history of authentic replication. Specifically, both AtG and TLK inherit this tradition of claiming verisimilitude through archaeological finds from The Vikings (1958) which includes the lead character Einar (Kirk Douglas) performing his own stunts running along the oars against the backdrop of a Norwegian fjord (Kelly 2011: 12; Tveskov and Erlandson 2007: 42). Those in AtG were clearly inspired by the Gokstad Ship (Ashby and Leonard 2018: 70-71; Snyder 2011: 42) even if the figureheads on the stern of the longboats are overly pronounced and without a precise parallel in the archaeological record. In contrast, the longships in TLK display a more accurate depiction of a figurehead, being smaller and thus less prominent and drawing on more informed seaworthy replica vessels, including the Sea Stallion of Glendalough which was built to replicate the Skuldelev 2 wreck (Crumlin-Pedersen 2010: 20-40). Unfortunately, there is again greater anachronism in the portrayal of the longships in TLK than AtG, because the slender, long warships shown in Seasons 1, 2 and 3 of TLK illustrate a phenomenon of the late Viking Age, not the 9th century (Crumlin-Pederson 2010: 99). In this regard, TLK is a victim of its over-enthusiasm by representing seagoing vessels designed specifically for war that are two centuries in advance of 9th-century craft. On balance, once again, At $G$ stands the test of time better in its representation of Viking longships of the 9th century than TLK.

\section{Discussion}

Film and television has become a medium in communicating and educating mass audiences and introducing them to historical and archaeological themes via entertainment (Hall 2009). Yet while between 1969 and 2015, public exposure to the material cultures, architectures and landscapes of the Early Middle Ages has been enhanced considerably, from Time Team to the availability of information via the World Wide Web (Bonacchi 2013: 119; Henson 2005), representations of archaeological periods can remain 'cringeworthy' in this popular medium (Moshenska 2017: 152). Often experts are not consulted on details of material culture, monuments and landscapes in productions that then claim to be recreating versions of the Early Middle Ages. Indeed, Henson (2005) states explicitly that the representation portrayed on film and television is not indicative of the views of professional archaeologists/historians, but rather the view of the producers. As Tveskov and Erlandson (2007: 45) argue, academic research is integral to these popular representations of the Vikings and exist in recursive relationship with them. Yet, it is clear that productions often afford Victorian and Edwardian archetypes precedence over details of archaeological research. In this instance, the vast increase in knowledge of Anglo-Scandinavian material culture from excavations and metal-detector finds over the last half century has demonstrably not made a significant impression on the portrayal of the later 9th century in England. While the way production companies operate is part of the picture, archaeologists and historians must be considered at least partly responsible for not telling their archaeological narratives in a compelling fashion and making their knowledge readily accessible via digital arena (Tveskov and Erlandson 2007: 47).

This situation is starkly illustrated by the comparisons made in this short chapter. The late 9th-century depictions of both AtG (1969) and TLK (2015-), despite being separated by over 40 years, display similar 
strengths, including their informed portrayal of ships, as they share an inheritance of early wellpreserved archaeological finds, and a persistent fascination in, and replication of, Viking longships in televisual and filmic productions. This is because the accurate portrayal of Norse seafaring is a successful inheritance of late 19th- and early 20th-century archaeological discoveries. Conversely, it is worth mentioning that neither deploy the 19th-century fantastical winged or horned helmets: both productions clearly aspire to represent an historical era rather than a time of fantasy and legend.

In other regards, however, there is little evidence of progression between AtG and TLK, with flagrant inaccuracies and anachronisms abounding in the latter as much as the former. Despite generations of new archaeological research it is quite disheartening to find that TLK's claims to create an immersive early medieval world are largely rhetorical and the show is working from a pre-1950s baseline of archaeological knowledge. Indeed, in many regards, from the portrayal of agricultural life to the helmets worn by the Anglo-Saxons and Danes, At $G$ is unquestionably a superior production in terms of accuracy than TLK considering the knowledge available at the time of production (Williams 2019). Likewise, as discussed above, some of the prominent swords are far less obviously fantastical in AtG and inspired by 9th-century high-status West Saxon metalwork. Hence, in some important ways, TLK is a regression, with far more limited research and respect for archaeological information by costume designs and set designers than in AtG.

Where TLK has the edge in artefactual terms is in a desire, evident in the uses of brooches (but also in saint's relics and martial gear), to implant specific archaeological objects into the storyline, from the Fuller brooch (Williams 2018b), Alfred Jewel (Williams 2018c) and the coffin of St Cuthbert (Williams 2018d) to the Pioneer Helmet (Williams 2019a) and the Bewcastle monument (Williams 2019b), even if the items are often represented with glaring errors in their form and function. This is also matched with considerable cross-fertilisation with the rival television show Vikings (2013-) in the preference for tattoos and elaborate eyeliner as a signature of Scandinavian male appearance. Indeed, it is perhaps to Vikings that we must turn to see a much closer synergy between recent academic research and popular fictional portrayals of the early Viking Age (Williams 2019c, Williams and Klevnäs 2019; Williams 2020). Certainly, it will be interesting to see if archaeological research is taken any more seriously in another 46 years time! However, in its deployment of artefacts inspired by archaeological finds, despite being a box-office flop, the 1969 Alfred the Great prevails in comparison with the popular recent television show The Last Kingdom in how it deploys dress accessories, swords and ships in its representation of the 9th century AD.

\section{Bibliography}

Ashby, S. and A. Leonard 2018. Vikings. London: Thames \& Hudson.

AtG Alfred the Great 1969. [DVD] Directed by C. Donner. United Kingdom: Metro-Goldwyn-Mayer.

Bonacchi, C. 2013. Audiences and experiential values of archaeological television: The case study ofTime team. Public Archaeology 12(2): 117-131.

Crumlin-Pedersen, O. 2010. Archaeology and the Sea in Scandinavia and Britain. Maritime Cultures of the North 3, Roskilde: The Viking Ship Museum.

Davidson, H.E. 1962. The Sword in Anglo-Saxon England: its Archaeology and Literature. Oxford: Oxford University Press.

Galway Advertiser 2018. The making of Alfred the Great. [online] viewed 20 January 2018, http://www. advertiser.ie/galway/article/5331/the-making-of-alfred-the-great

Graham-Campbell, J. 2013. Viking Art. London: Thames \& Hudson. 
Hall, M. 2009. Making the past present: cinematic narratives of the Middle Ages, in R. Gilchrist and A. Reynolds (eds) Reflections: 50 years of Medieval Archaeology 1957-2007: 489-511, Leeds: Maney.

Harty, K.J. (ed.) 2011. The Vikings on Film. Jefferson, N.C.: McFarland.

Henson, D. 2005. Television Archaeology: Education or Entertainment? History in British Education (first conference), 14-15 February 2005, Institute of Historical Research. (Unpublished), viewed 20 Jan 2018, https://sas-space.sas.ac.uk/4329/1/Television_Archaeology_Education_or_Entertainment.pdf

Hines, J. 1997. A New Corpus of Anglo-Saxon Square-Headed Brooches. Woodbridge: Boydell.

Hinton, D. 2005. Gold \& Gilt, Pots \& Pins: Possessions and People in Medieval Britain. Oxford: Oxford University Press.

Kelly, K.C. 2011. The trope of the scopic in The Vikings (1958), in K. Harty (eds) The Vikings on Film: Essays on the Depictions of the Nordic Middle Ages: 9-23. Jefferson NC: McFarland.

Kershaw, J. 2013. Viking Identities: Scandinavian Jewellery in England. Oxford: Oxford University Press.

Moshenska, G. 2017. Archaeologists in popular culture, in G. Moshenska (ed.) Key Concepts in Public Archaeology: 151-165. London: UCL Press.

Ó Flionn, R. 1989. Secular metalwork in the eighth and ninth centuries, in S. Youngs (ed.) 'The Work of Angels' Masterpieces of Celtic Metalwork, 6th-9th Centuries AD: 72-124. London: British Museum Press.

Paterson, C., A.J. Parsons, R.M. Newman, N. Johnson and C. Howard Davis 2014. Shadows in the Sand: Excavation of a Viking-Age Cemetery at Cumwhitton, Cumbria. Lancaster Imprints 22, Lancaster: Oxford Archaeology North.

Pestell, T. 2015. Imports or immigrants? Reassessing Scandinavian metalwork in Late Anglo-Saxon East Anglia, in D. Bates and R. Liddiard (eds) East Anglia and its North Sea World in the Middle Ages: 230-255. Woodbridge: Boydell.

Snyder, C. 2011. 'To be, or not to be' - King: Clive Donner's Alfred the Great, in K. Harty (ed.) The Vikings on Film: Essays on Depictions of the Nordic Middle Ages: 39-43. Jefferson, N.C.: McFarland.

SomeHistoryStuff 2016. The Last Kingdom - Creating the world. [Video file], 27 May 2016, viewed 15 Jan 2017, https://www.youtube.com/watch?v=vAXZ0EXzB7E\&t=532s

Soulat, J. 2016. Réexamen du mobilier de type mérovingien de la nécropole de Buckland à Dover (Kent), in I. Riddler, J. Soulat and L. Keys (eds) The Evidence of Material Culture: Studies in Honour of Professor Vera Evison: 17-34. Autun: Éditions Mergoil.

TLK The Last Kingdom 2015-. [Television Programme]. United Kingdom: Carnival Film and Television

Tveskov, M.A. and J.M. Erlandson 2007. Vikings, vixens and Valhalla. Hollywood depictions of the Norse, in J.M. Schablitksy (ed.) Box Office Archaeology: 34-50. Walnut Creek CA: Left Coast Press.

Webster, L. 2012. Anglo-Saxon Art. London: British Museum Press.

Williams, H. 2018a. The Last Kingdom Season 1: Fire is All! Mar 2018, viewed 8 Aug 2019, https:// howardwilliamsblog.wordpress.com/2018/03/18/the-last-kingdom-season-1-fire-is-all/

Williams, H. 2018b. The Last Kingdom Season 2: Fuller is All! 4 May 2018, viewed 8 Aug 2019, https:// howardwilliamsblog.wordpress.com/2018/05/04/the-last-kingdom-season-2-fuller-is-all/

Williams, H. 2018c. The Last Kingdom Season 2: Jewel is All! 7 May 2018, viewed 8 Aug 2019, https:// howardwilliamsblog.wordpress.com/2018/05/07/the-last-kingdom-season-2-jewel-is-all/

Williams, H. 2018d. Coffin is All! St Cuthbert in The Last Kingdom Season 2, 2 Aug 2018, viewed 8 Aug 2019, https:// howardwilliamsblog.wordpress.com/2018/08/02/coffin-is-all-st-cuthbert-in-the-last-kingdom-season-2/ 
Williams, H. 2019a. Boars are All: Helmets in The Last Kingdom Season 3, 18 May 2019, viewed 8 Aug 2019, https://howardwilliamsblog.wordpress.com/2019/05/18/boars-are-all-helmets-in-the-last-kingdomseason-3/

Williams, H. 2019b. Stone sculpture in The Last Kingdom Season 3 - Bewcastle is all! 8 June 2019, viewed 8 Aug 2019, https://howardwilliamsblog.wordpress.com/2019/06/08/stone-sculpture-in-the-lastkingdom-season-3-bewcastle-is-all/

Williams, H. 2019c. Death's drama: mortuary practice in Vikings Season 1-4, in H. Williams, B. Wills-Eve and J. Osborne (eds) The Public Archaeology of Death. 155-182. Sheffield: Equinox.

Williams, H. 2020. The real Vikings: the early medieval world behind the hit drama, History Extra, 17 Jan 2020, viewed 18 Jan 2020, https://www.historyextra.com/period/viking/real-history-behind-dramavikings-ragnar-lothbrok-who-how-accurate-fact-fiction/

Williams, H. and A. Klevnäs 2019. Dialogues with the dead in Vikings, in P. Hardwick and K. Lister (eds) Vikings and the Vikings: The Norse World(s) of the History Channel Series, 128-152. Jefferson, NC: McFarland Press.

Wilson, D.M. 1964. Anglo-Saxon Ornamental Metalwork 700-1100. London: British Museum. 